A Journal of Culture, English Language, Teaching \& Literature ISSN 1414-3320 (Print), ISSN 2502-4914 (Online)

Vol. 17 No. 1; July 2017

Copyright (c) Soegijapranata Catholic University, Indonesia

\title{
Solving the Students' Problems in Writing Argumentative Essay through the Provision of Planning
}

\section{Lestari Setyowati, Sony Sukmawan and Mohamad Anan Latief}

English Education Study Program, STKIP PGRI, Pasurunan, East Java, Indonesia; Faculty of Cultural Studies, Unversitas Brawijaya, Malang, East Java, Indonesia; Faculty of Letters, Universitas Negeri Malang, East Java, Indonesia

email: lestari.setyowati@yahoo.co.id; sony_sukmawan@ub.ac.id; a.adnanlatief@gmail.com

Received: 17-06-2016

Accepted: 20-07-2017

Published: 11-08-2017 


\title{
Solving the Students' Problems in Writing Argumentative Essay through the Provision of Planning
}

\author{
${ }^{1}$ Lestari Setyowati, ${ }^{2}$ Sony Sukmawan, and ${ }^{3}$ Mohamad \\ Anan Latief
}

${ }^{1}$ lestari.setyowati@yahoo.co.id; 2 sony_sukmawan@ub.ac.id;

3a.adnanlatief@gmail.com

${ }^{1}$ English Education Study Program, STKIP PGRI Pasurunan, East Java, Indonesia

${ }^{2}$ Faculty of Cultural Studies, Unversitas Brawijaya, Malang, East Java, Indonesia

${ }^{3}$ Faculty of Letters, Universitas Negeri Malang, East Java, Indonesia

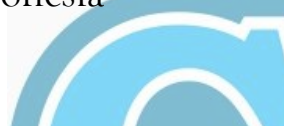

Abstract: Most Indonesian students who are learning English often consider writing as not only the most difficult skill to master, but also a demanding activity. To help them cope these problems, the application of planning in the writing process seems to be a solution. This study attempts to find out howdifferent planning formats can improve EFL students' writing performance in argumentative essays. The subjects of the studywere the fourth semester students taking essay writing class. The research was conducted from May to June 2015, consisting of three cycles in Classroom Action Research design by using different planning types, namely rough drafting and outlining strategy in which each cycle consisted of two meetings. The students' compositions were measured by using primary trait scoring rubric for argumentative essay. The result of the study shows that the provision of planning is effective to improve the students' performance in writing argumentative essay. The effectiveness of different types planningdepends on the students' preference of which to use.

Key words: planning, argumentative essay, writing performance. 
Setyowati, L., Sukmawan, S., \& Latief, M. A., Solving the Students' Problems 87 in Writing Argumentative Essay through the Provision of Planning

\begin{abstract}
Abstrak: Sebagian besar mahasiswa Indonesia yang sedang belajar bahasa Inggris sebagai bahasa asing sering menganggap keterampilan menulis adalah satu keterampilan berbahasa yang paling sulit untuk dikuasai diantara keterampilan berbahasa lainnya. Hal ini dikarenakan kompleksitas penguasaan keterampilan menulis itu sendiri. Untuk membantu mereka mengatasi masalah ini, penerapan perencanaan dalam proses penulisan tampaknya menjadi satu solusi yang patut dipertimbangkan. Penelitian ini mencoba untuk mengetahui bagaimana bentuk perencanaan yang berbeda dapat meningkatkan kinerja menulis mahasiswa dalam mengarang esai argumentasi. Subyek penelitian ini adalah mahasiswa semester IV yang mengambil mata kuliah menulis esai. Penelitian ini dilakukan pada bulan Mei-Juni 2015. Terdapat tiga siklus dalam desain Penelitian Tindakan Kelas ini dengan menggunakan jenis perencanaan yang berbeda yaitu menggunakan draft kasar dan outline.Setiap siklus terdiri dari dua pertemuan. Hasil karangan mahasiswa diukur dengan menggunakan rubrik primary trait scoring untuk esai argumentatif. Hasil penelitian menunjukkan perencanaan menulis mampu meningkatkan kinerja mahasiswa dalam menulis esai argumentasi. Efektifitas perencanaan menulis ini tergantung pada kesukaan mahasiswa untuk memilih jenis format perencanan mana yang akan digunakan.
\end{abstract}

Kata kunci: perencanaan, esai argumentasi, kinerja menulis.

\title{
INTRODUCTION
}

In this era, people are gradually aware that the ability to write has become an important skill to be mastered by those who want to be recognized in the global world.The act of writing makes the thoughts visible and transferable to other people. However, to be able to write well is not easy at all, especially to write in the foreign language like English.

It is not unusual to find writing classess which are not engaged. Some factors may cause this problem. The first factor might come from the the way the teaching of writing is conducted. It is a common knowledge that in EFL writing classess in private universities, the writing lecturerhas difficulties to makethe course challenging as most of the instructions use 'write-thencollect'activities without giving further information of how to approach and finish the task. Moreover, the topic given might not be interesting enough for the students to write. When the topic is not challenging, a student-writer will have problems even before he/she puts the pen on the paper. The 
second factor might come from the complexity of writing itself. From the students' points of view, writing in English is a challenging activity because they have to make use of almost allof their linguistics skills to write, such as the skill in using vocabulary,the skill in using grammar, the skills in gathering information, and skill in organizing the information to produce a good essay.

Based on the observation during the preliminary study in STKIP PGRI Pasuruan, the students in this institution often see that a good writing is one that is perfect in grammar and lengthy in the number of words. Therefore, if the writing does not use good grammar and is not lengthy, they judge themselves as "not good writers". This is of course is not totally true. Ideas which flow smoothly, logically and communicatively for the intended audience often becomes the characteristics of a good writing. When writing is seen as a means of communication, effective communication becomes a paramount importance. To achieve this, the words and ideas should be ordered well on the page in ways that make sense to a reader. The process of lining up these words and ideas is more complicated than it may seem. As most writers have experienced, the ideas do not necessarily arise in a linear pattern since mostly they are scattered in the writers' mind.

Typically through the act of writing, the logical relationship that develops the idea is created into something meaningful. The action of putting ideas into words and arranging them logically helps the readers see, create, and explore new connections. So not only does a writer need to "have" ideas, but the writer also has to arrange them neatly and logically before putting them on paper, that is, to "write" them for a reader, in order for those ideas to be meaningful. To conclude, a good writing should be seen from how the ideas are related, understood, and acceptable by readers.

This present study is basically triggered by the students' problems in EFL writing class in STKIP PGRI Pasuruan. Most of them have two major problems in learning to write, namely, what to write and how to start. "What to write" problem deals with how to generate ideas whereas the second one deals with how to start writing for a composition. These two problems are basically the problems that most EFL learners encounter when they are assigned to write in English. 
Setyowati, L., Sukmawan, S., \& Latief, M. A., Solving the Students' Problems 89 in Writing Argumentative Essay through the Provision of Planning

\section{LITERATURE REVIEW}

The term "planning" has several definitions. In the regular definition of planning, the writers work out what to say first then work on expressing their meaning as effectively as possible in the actual writing activity that follows. The regular definition of planning mostly refer to the explicit plan done before the actual writing task (Galbraith and Torrance, 2004). Interestingly, the term planning for Galbraith and Torrance (2004, p. 64) does not refer only to the explicit plan mostly done before the writing task, but the term planning can also be done during their actual writing activity and in which content may develop over a series of drafts before it finally comes to the end product. Galbraith (2004) called this as interactive strategy. The interactive strategy aims at producing the initial draft freely to express thoughts about the topic. Thus, it can be concluded that planning can be done before or during the writing task. To date, two widely-known writing strategies are found in the writing research (Kieft, et al., 2007), namely planning writing strategy in which writers work out what they want to say before setting pen on paper, and revising writing strategy-start producing a full text once they have worked out what they want to say. Torrance and Galbraith (2006) call this revision writing strategy as interactive approach (p. 64), while to Kellog $(1990,1996)$, this revision strategy is similar to rough draft strategy.

In the planning activity in general, there are many strategies before a writer writes. The strategies called the prewriting activities include brainstorming, cubing, clustering, listing, looping, and freewriting (Baroudy, 2008). As stated by Kellog (1999), freewriting is the rough version of a drafting activity. Since rough drafting and prewriting are both placed in the planning stage in the writing process, they function to generate and organize ideas, to set the goal to reach the purpose of the composition (Flower and Hayes, 1981, p. 370).

In the field of L1 writing, the results of pre-task planning (planning prior to composing) shows consistent effect on L1 writers' texts. Most studies conducted by writing experts, such as Kellog $(1988,1990,1999)$ yield results that pre-task planning-specifically outlining-is effective in improving L1 writing quality hollistically. Similarly, the result of study conducted by Kieft et al., (2007) also shows that both strategies are equally effective.Having reviewed the literature, the researcher was interested to solve the students' 
problems in generating ideas for writing argumentative essay through the provision of planning, before and during the actual writing task.

On the ground of the background of the study presented above, the present study proposes to solve the students' problem in writing argumentative essay. Thus, the research problem is posed as: "How can the students' writing performancein argumentative essays be improved through the provision of planning?"

Ellis (2005) distinguishes two broad kinds of planning; pre-task planning and within-task planning. Pre-task planning is a kind of planning which happens before performing the task, whereas within-task planning refers to the kind of planning which occurs during the time of performance of a task. However, there is another term which refers to within-task planning which is called on-line planning. These two terms are often used interchangeably, such as in Ellis and Yuan's paper (2003), which refer to similar meaning.

Pre-task planning and within-task planning are different in terms of when planning is conducted and the format of the planning. In the former, the students have an opportunity to plan what to say and how to write it out before their performance. The strategies for pre-task planning might include cubbing, clustering, and mapping (Ojima, 2006), outlining (Kellog, 1988, 1990). Whereas the strategy for within-task planning is similar to rough draft strategy as proposed by Kellog (1999) through its freewriting activity.

Ellis (2005) further categorizes pre-task planning into two kinds; rehearsal and strategic planning. Meanwhile, within-task planning refers to planning done during the actual writing task (Ellis, 2005).Ellis and Yuan (2003) research on pre-task planning and within-taskplanning in written production shows that care within task planning enables learners to write with more syntaxtically complex sentences (complexity) and more correct clauses and verbs (accuracy). Whereas Ghavamnia et al.'s (2013) study shows that the availability of pre-task planning can produce more complex and fluent writings, whereas the within-task planning enables learners to produce more accurate writing performance.

For SLA researchers, planning is important because "it links in with the current interest in the role of attention in language learning" (Ellis, 2005). One of the most influential model in task-planning within writing 
Setyowati, L., Sukmawan, S., \& Latief, M. A., Solving the Students' Problems 91 in Writing Argumentative Essay through the Provision of Planning

context is the Flower and Hayes'model (1981). In their article, "A Cognitive Process Theory of Writing" (1981), Flower, L. and Hayes, J.R. report the findings of their study using a new model to observe the processes writers employ in the act of composition. Rejecting traditional research methods, they begin the idea of writing as a process, that it comprises of several stages.

Flower and Hayes Model (1981) distinguishes three basic systems involved in written text production. First is Planning which entails the process of generating ideas with organization and goal settingas components. Second is translating which means putting the ideas on the paper (writing/composing). The thirdis reviewing that consists of the act of reviewing under the control of a Monitor. The writer evaluates what he or she has written and then changes the text to suit the developing concept of the document. This activity operates based two kinds of information: the task environment, which consists of the writing assignment and the production of the text, and the knowledge stored in the long-term memory, which consists of the topic knowledge, the audience, the plan, the grammar knowledge, and the text knowledge. They argue that Pre-Writing strategy helps improve the quality of composition by "calling attention to planning and discovery as legitimate parts - of the writing process" (Flower and Hayes, 1981, p. 367). They conclude that the source of creativity comes from the writer's ability to create goals and to generate ideas. And this important part is placed in the planning stage.

\section{METHODOLOGY}

The study employs Classroom Action Research (CAR). Koshy (2005) defines action research as an enquiry which is carried out in order to understand, evaluate, and then modify educational program to improve educational practice. One of the proposed designs of action research is Classroom Action Research (CAR). The design is based on the consideration that the teacher as researcher attempts not only to solve the problem in the particular classroom, but also to improve the quality of teaching. One of the distinctive features of CAR design is the cyclesto be implemented in the research; each of which consist of planning, acting, observing, and reflecting (Kemmis and Taggart, 2007).

A preliminary study was conducted for this research by giving the students a pretest to find out the problems encountered when writing an 
argumentative essay. The students' compositions were rated by two writing teachers. The students' compositions in the pretest were scored using Jacobs ESL Composition profile, meanwhile their compositions after each cycle were rated by using Primary Trait Scoring Rubric developed by Latief (1990).Babbin and Horrison (1999) said that Primary Trait Scoring is mostly helpful in responding to the students' draft, and in encouraging and shaping revision.Similarly, the criteria of success was determined prior the cycles were excecuted. The success criterion stated was the classroom action research would be stopped if $80 \%$ the students showed the ability to choose and defend a position on an issue and demostrate the ability to support their position by giving at least two relevant evidences.

Intermediate ELT students taking Writing III class in their fourth semester at College of Teachers Training and Education (STKIP) PGRI Pasuruan participated in this study. This class was taken because of their low writing achievement as compared to other classes.However, only 18 students were taken as the subjects of the study on the basis of the attendance and papers submitted during the research.

Three cycles were conducted in which each cycle consists of two meetings, 90 minutes each. The first cycle was conducted on May 26 and May 29, 2015. The second cycle was conducted on June 2, 2015 and June 4, 2015. Meanwhile, the third cycle was conducted on June 6, 2015 and June 9, 2015. Based on the English Language Teaching syllabus, the fourth semester students should have the ability to write expository and argumentative essays by using different types of paragraph development. This research, however, focused on argumentative essays.

In the first cycle, the students wereasked to write a 250-word argumentative essay with refutation. In the first meeting of the first cycle, the students were taught how to make refutation for an argumentative essay. The topic of cycle 1 was Kids and Smartphone. In the planning of cycle 1, the students were asked to respond to the a short article taken from an authentic material in the web and to make a plan through freewriting activity in 10 minutes before they started writing their full draft. The purpose of giving the article of a controversial issue was to trigger the students' knowledge on the topic so that they had a clear purpose to write whether they should agree or disagree. In the implementation of cycle 1 , the article was discussed first in the class. After the discussion, the students were asked to plan their writing 
Setyowati, L., Sukmawan, S., \& Latief, M. A., Solving the Students' Problems 93 in Writing Argumentative Essay through the Provision of Planning

by using freewriting activity in 10 minutes. The writing stage lasted for 40 minutes in which they had to write a 250-word essay under the topic Should We Let Kids Have Smartphones? Intheir essay, the students were asked to show at least a refutation. Revising and editing then followed.During the observation stage, the researcher observed whether in 10 minutes, the students were able to generate ideas by using freewriting activity to make a rough draft. The researcher also observed the approximate number of sentences made by the students in 10 minutes during the rough drafting. The result of the observation shows that in 10 minutes, the students had problems to make a rough draft by using freewriting activity as they were only able to generate $5-8$ sentences. In short, the students were not accustomed to write their ideas loosely in 10 minutes. Based on the observation, most of the students spent their 10 minutes time day dreaming as if thinking what should be written in 10 minutes. However, few students were able to develop their rough draft into a 250 words essay. The result of the reflection also shows that only $50 \%$ of the students were able to reach the criteria of success. Based on the data, the researcher decided to continue the cycle to solve the students' problems in generating ideas by introducing different format of planning.

In the second cycle, the students were taught how to open and close an argumentative essay. The topic for cycle 2 was Plastic Bags and Society. In the planning of cycle 2, a new format of planning was introduced, named outlining. Similar to cycle 1 , the students were given an authentic material of an article taken from the web entitled The Use of Plastic Bags in Everyday Life. In cycle 2, it was planned that the students should make an outline in 10 minutes before they started their actual writing task. During the implementation, the article was discussed first with the sole purpose of preparing the students' background knowledge. After that, the students were given an argumentative map to fill. In the outline, the students should state their position whether to agree or disagree. There were three reasons that students should fill, each of which should be completed with three personal examples and details. The last line of the outline asked the students to make a conclusion. To fill the outline, the students were given 10 minutes to generate their ideas. After that, they were given 40 minutes to translate their outline into a composition. In the observation, the researcher observed the students' activity during the completion of the outline in 10 minutes. However, the result of the observation showed that many of the argumentative maps were not fully filled which meant that the ideas were not fully generated in 10 minutes. When some of the students were interviewed 
about their feeling of using outlining, the students had different answers. Some of them said that 10 minutes planning was not enough, and other said they did not know what to fill in the the map. Surprisingly, very few students said that an outline eased them to get ideas although the time was not sufficient to fill all the lines. The result of the reflection of cycle 2 showed that only $44.5 \%$ were able to reach the criteria of success. There was a decrease in the percentage of the students who were able to reach the criteria of success when it was compared to cycle 1 . It was found out that the main problem was time for planning and the preferences of planning format. Therefore, the researcher decided to continue the cycle into cycle 3.

In the third cycle, the students learned to use at least one type of rhetorical organization to develop an essay, cause and effect, or problem solution. The topic of cycle 3 was money and happiness. In the planning stage, two different format of planning were In the prewriting stage, there was a class discussion which talked about whether mooffered to the students. They may choose the format of planning which they felt comfortable to use before they began writing. The time for planning was also doubled which meant that they had 20 minutes to plan their writing either using rough drafting or outlining. In the implementation stage, unlike cycle 1 and cycle 2 , the students were not given an authentic material to read. Instead, a class discussion was set up to talk about whether money can/cannot make people happy. The goal of this discussion was to prepare the students' schemata before writing. After 20 minutes-discussion, the students were asked to plan their writing. In this cycle, they were given freedom to choose whether to use rough drafting or explicit planning. After 20 minutes of planning, new sheets of paper were distributed to the students so that they could performed their actual writing task. Revising and editing then followed. In the observation, the researcher observed the students' activity during the planning. The students who prefered to use outlining, made their own mental map on the paper in the form of lines or circles in which each of these consists of points they would discus in the composition. While other who prefered rough drafting through freewriting, started their composition right away. The result of the reflection showed that $88.9 \%$ of the students were able to reach the criteria of success. As the criteria of success had been reached, the cycle was stopped.

Three instruments were used in this research: direct writing test, observation, and unstructured interview.The final drafts of the students' 
Setyowati, L., Sukmawan, S., \& Latief, M. A., Solving the Students' Problems 95 in Writing Argumentative Essay through the Provision of Planning

writing in each cycle were collected along with their draft of their planning, either rough drafting or outlining. The students' compositions produced in the end of each cycle were used as the posttest. To score the compositions collected after each cycle, the writer used Primary Trait scoring for argumentative essay developed by Latief (1990). A five-point scale from 0 to 4 was used as the rubric. Writerswould get score 0 if they were not able to state a claim,while those who can show their stand on an issue but do not provide relevant evidence to support the claim would get the score 1 . In addition, students would get the score 2 if they could take a claim on the issue and provide only one relevant evidence. Score 3 would be given if they can provide two pieces relevant evidence, and score 4 would be given if they can provide three to four pieces of relevant evidence that strongly support the claim.

The second instrument was observation. In this case, the researchers were helped by a writing lecturer who acted as an observer. She observed the teaching and learning process with a guide of observation checklist, lesson plan, and field note. She also observed which students seemed to have problems and difficulties during the process of learning.

The third instrument was the unstructured interview. The researchers did interviews with some students at random to find out their feelings and opinions about the duration of planning they would like to have, about their preferences of different planning formats, and their reasons why liked particular planning type. The interview was conducted in the end of cycle 2

\section{RESULTS}

Prior the cycles were implemented, the researcher had decided to set the criteria of success in relation to the scoring rubric of argumentative essay used. The criteria of success said that the cycles would be stopped if $80 \%$ the students fall in the category 3 of primary Trait Scoring Guide for argumentative essay used in the study.

Although the criteria of success did not use mean to measure the students' writing, it was interesting to discuss thefluctuation of the mean in each cycle. The mean of cycle 1 is 2.22 with the most frequent score is 3 . Meanwhile, in cycle 2, the mean increases slightly into 2.44 with the most frequent score is 2 . The high improvement of the mean can be seen in cycle 
3 in which it increases to 0.83 , which gives the values of 3.27 with the mode of 3 .

Table 1:

\section{Frequency Distribution Result}

\begin{tabular}{|c|c|c|c|c|c|c|c|}
\hline \multicolumn{2}{|c|}{ Rubric scores } & \multicolumn{2}{|l|}{ cycle1 } & \multicolumn{2}{|l|}{ Cycle 2} & \multicolumn{2}{|l|}{ Cycle 3} \\
\hline & & Frequency & Percen & Frequency & Percent & Frequency & Percent \\
\hline & 1,00 & 5 & 27,8 & 3 & 16,7 & 0 & 0 \\
\hline & 2,00 & 4 & 22,2 & 7 & 38,9 & 2 & 11,1 \\
\hline \multirow[t]{3}{*}{ Valid } & 3,00 & 9 & 50,0 & 5 & 27,8 & 9 & 50,0 \\
\hline & 4,00 & 0 & 0 & 3 & 16,7 & 7 & 38,9 \\
\hline & Total & 18 & 100,0 & 18 & 100,0 & 18 & 100,0 \\
\hline
\end{tabular}

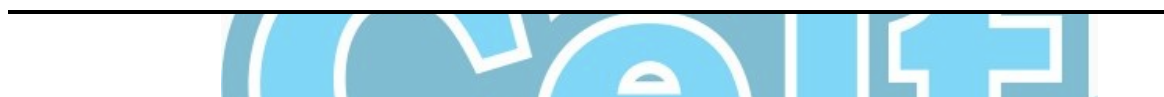

From Table 1, it can be seen that the criterion of success was not reached in cycle 1 and cycle 2 . The criterion of success states that the cycle would be stoped if $80 \%$ of the students were able to state his position on an issue and have the ability to support the claim position by giving at least two relevant evidences. This criterion of success falls in point 3 of Latief's rubric (1990). If Table 2 is summed up, in cycle 1, there was only $50 \%$ of the students who were able to reach the criteria of success. Suprisingly, in cycle 2 , there was a decrese as compared to the previous cycle in the percentage of the students who were able to reach the success criteria (44.5\%). Only that in cycle 3, the criteria of success was able to be achieved. Better yet, the students were able to pass the criteria of success as there was $88.9 \%$ of them who were able to show his position on an issue and support his claim with at least two relevant evidences. To have a better view of the students' development in each cycle, the data are presented in the histogram. Figure 1.

Figure 1 shows the skewedness of the students' scores in each cyle. It can be noted that there is a shift in each cyle. In cycle 1 , the scores tend to be skewed to the left as none of them were able to reach the highest point in the scoring rubric. In cycle 2, the score distribution appears normal, as those who 
Setyowati, L., Sukmawan, S., \& Latief, M. A., Solving the Students' Problems 97 in Writing Argumentative Essay through the Provision of Planning

reached the lowest scores and the highest scores are equal in number, while majority of the students fall in the middle. More promising figure can be seen in cycle 3 . In cycle 3 , the scores skewed to the right which shows a good sign of the improvement.

Figure 1:

The Development in Each Cycle
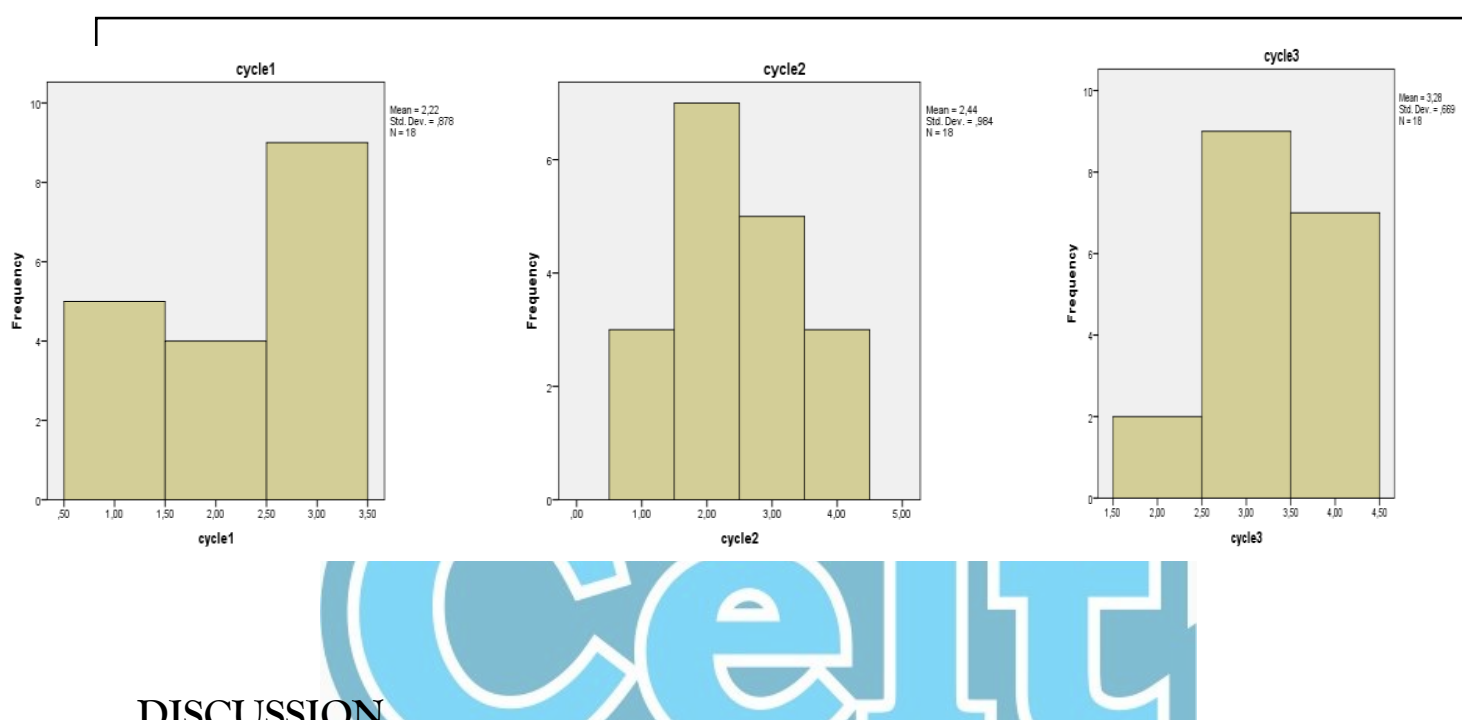

DISCUSSION

Previous studies have confirmed that planning is beneficial for the learners to improve the quality of their target language production. However, there was no sufficient information in what way planning does help. There are some possible explanations of decrease performance from cycle 1 to cycle 2, and the improvement from the first two cyles to the third cycle, namely the planning time, and the preferences of the format of planning.

There is no clear agreement how long students should plan their performance. Previous research in planning studies have different length of planning time given to their subjects of study. It ranges from 5 minutes(Philp et al., 2006) to 10 minutes (Ellis and Yuan, 2003; Rahimpour and Jahan, 2011; Ong and Zhang,2010). The result of their studies show that 5 to 10 minutes time to plan is sufficient for them. This is understandable since the subjects of their study lived in the area where English is as the first language (Philp et al., 2006) or a second language (Ong and Zhang,2010) so that outside the classroom, the subjects had rich exposure to the target 
language.But for Indonesian learners who live in a place where English is as a foreign language, and in which target language exposure is scarce, 10 minutes time might not be sufficient.

In this research, it was found out that the students had problems with 10 minutes time to plan their writing, either by using outlining or freewriting. It can be seen from the result of cycle 1 and cyle 2. The difference between cycle 1 and cycle 2 was the format of the planning the students used. In cycle 1, the students were asked to freewrite their composition in 10 minutes, and in cycle 2, they were asked to outline their essay by using argumentative map.

The second possible explanation is the students' pereferences of the format of planning. In the institution, most of the writing classes adopt product approach to teaching writing. As a result, the students somehow were accustomed to 'write-then-collect' way of writing.Although many students were not able to generate ideas well by using freewriting in 10 minutes, it was not surprising to find out if $50 \%$ of them were able to reach the criteria of success in cycle 1. Freewriting activity, according to Kellog (1999:132) is the "extreme version of rough draft strategy". During the freewriting activity, the writer translates his ideas at the moment of writing without thinking of how to organize the thoughts. This type of strategy is similar to Kieft's et al., (2007) revising strategy. It is called as revising strategy because after producing the first rough draft, the students had a chance to revise it into the second draft. In this research, after the students did some freewriting activities, they rewrote and revise the second draft before it was submitted.

In cycle 2, it was surprising to see that there was a decrease in the percentage of the students' performance. The decrease of almost $6 \%$ was something intriguing. Using systematic planning prior composing, theoritically, can help students to write better. Some students however, seemed uncomfortable with this 'plan-first' strategy. The result of the interview showed that they did not know what to fill in the argumentative map. As a result, their 10 minutes time to fill the argumentative map was not used wisely since many spaces in the map were still empty. Based on the data, it was concluded that some students prefered to use frewriting activity to plan their writing, while other felt more comfortable with outlining. 
Setyowati, L., Sukmawan, S., \& Latief, M. A., Solving the Students' Problems 99 in Writing Argumentative Essay through the Provision of Planning

The solution offered in cycle 3 , in which the students were let free to choose their own planning strategy, has shown a promising improvement on the students' writing performance. This is confirming Kieft's et al., (2007) finding which states that effectiveness of planning before writing and the other revising after writing depends on the students' own writing strategies preferences. In their research, the result also shows that students with a natural tendency toward planning benefit most from instruction that emphasizes planning, while others who had undeveloped strategies, or who had a tendency not to plan before writing, benefitted more from instruction that emphasized revision. Taken into this classroom action research context, this seems to be the possible explanation of the improvement in cycle 3 . The data from cycle 3 shows that none of the students fall in the category 1 in the Primary Trait Scoring Guide, unlike cycle 1 and 2. In short, what ever the format of planning given to the students, they are equally effective to improve the students' writing performance. However, there are some considerations that writing lecturer need to take into account, namely the time length of planning and the students' preferences of planning type.

There are some limitations in this research. First of all, this research only focuses on the idea development. As a result, other writing aspects were not counted, such as the language, vocabulary, and mechanics. Because the problems in the language were not noticed, the students problem in the language remains unsolved. To be able to solve this problem, future researchers can use other scoring rubric which is more sensitive than the primary trait scoring used in this study.

The second limitation of this study is the instruments used in the study. More in-depht information basically can be taken from the study if only the researcher used more structured interview. The unstructured interview used in the study might not reflect the reality of all subjects of the study as not all students were interviewed. Furthermore, this research basically can generate more information on the students' preferences on the planning strategies they used. To get this data, questionaires can be distributed to the students after the cycle is excecuted. Therefore, future researchers can make use of more instruments to get more information so that more understanding on the nature of planning they students use can be provided.

Lastly, this study employed classroom action reserach in which its main purpose is to solve the students' problems in writing. If more 
information to be obtained in relation to cause and effect relationship, experimental research design needs to be employed. After all, the result of the study in this research is only applicable to the subjects under this study.

\section{CONCLUSION}

This research is basically triggered by the students' problem in generating ideas during their writing course. Feeling obliged to solve this problem, a classroom action research was conducted in three cycles. The result of the study shows that the provision of planning is beneficial to improve the students' writing performance in argumentative essay. Despite of its effectiveness, there are some considerations that should be taken into account. Firstly, the time length of planning and the students' preferences of the planning strategy format need to be seriously planned 'by considering the characteristics of EFL learners. Based on the result of the study, it was found out that the students needed approximately 20 minutes to plan their writing either by using rough drafting activity or outlining. Secondly, the result of the study also shows that when the students were given the freedom to choose their own planning strategy that made them comfortable, they were able to show better performance in their essay.

\section{REFERENCES}

Babbin, E. H \& Harrison, K. (1999).Contemporary Composition Studies: A Guide to theorists and terms. London: Greenwood Publishing Group.

Ellis, R. (2005). Planning and task-based research: theory and research. In R. Ellis (Ed.), Planning and task performance in a second language, pp. 3-34. Amsterdam: John Benjamins.

Ellis, R \& Yuan, F. (2003). The Effects of Pre-Task Planning and On-Line Planning on Fluency, Complexity and Accuracy in L2 Monologic Oral Production. Applied Linguistics , 24 (1): 1-27.

Flower, L \&Hayes, RJohn,.(1981). A Cognitive Process Theory of Writing. College Composition and Communication, 32 (4): 365-387. 
Setyowati, L., Sukmawan, S., \& Latief, M. A., Solving the Students' Problems 101 in Writing Argumentative Essay through the Provision of Planning

Galbraith, D., \& Torrance, M. (2004). Revision in the context of different drafting strategies. In L. Allal, L. Chanquoy, and P. Largy (Eds.), Revision of written language: Cognitive and instructional approaches (pp. 63-86). Dordrecht, NL: Kluwer Academic Publishers.

Ghavamnia, M., Tavakoli, M., \& Esteki, M. (2013).The Effect of Pre-Task and Online Planning Conditions on Complexity, Accuracy, and Fluency on EFL Learners' Written Production.Porta Linguarum 20:3143

Kellog, R. T. (1988). Attentional overload and writing performance: Effects of rough draft and outline strategies. Journal of Experimental Psychology: Learning, Memory, and Cognition, 14 (2): 355-365.

Kellogg, R.T. (1990). Effectiveness of prewriting strategies as a function of task demands. American Journal of Psychology, 103 (3): 327-342.

Kellogg, R.T. (1996). A Model of Working Memory in Writing. In C.M. Levy \& S. Ransdell (Eds.), The Science of writing: Theories, Methods, Individual Differences, and Applications (pp. 57-71). Mahwah, NJ: Lawrence Erlbaum.

Kellog, R. T. (1999). The Psychology of Writing. Oxford: Oxford University Press. $\quad$ Retrieved 24 December 2014, from https://books.google.co.id/books?id=SE1Z eQ16V9AC \&pg= PA126\&lpg=PA126\&dq=mental + outline + in + writing $\&$ source.

Kemmis, Stephen \& McTaggart, Robin. (2007). Participatory Action Research: Communicative Action And The Public Sphere. (Online). Retrieved 20 March 2013, fromhttp://www.sagepub.com/upmdata/21157_chapter_10.pdf

Kieft, M, Rijlaarsdam G, Galbraith D, \& Van den Bergh H. (2007). The effects of adapting a writing course to students' writing strategies. British Journal of Educational Psychology. 77, 565-578.

Koshy, V. (2005). Action Research for Improving Practice: A Practical Guide. Great Britain: TJ International Ltd.

Latief, M.A. (1990). Assesment of English Writing Skills for Students of English as aForeign Language at the Institute of Teachers Training and Education IKIP 
102 Celt: A Journal of Culture, English Language Teaching and Literature, Volume 17, Number 1, July 2017, pp. 86 - 102

Malang Indonesia. Unpublished Ph.D. Disertation. Iowa: Graduate College of the University of Iowa.

Ojima, M. (2006). Concept mapping as pre-task planning: A Case Study of Three Japanese ESL Writers. System.34 (4): 566-585.

Ong, J. \& Zhang, L.J. (2010). Effects of task complexity on the fluency and lexical complexity in EFL students' argumentative writing. Journal of Second Language Writing (19): 218-233

Philp, J. Oliver, R., \& Mackey,A. (2006). The impact of planning time on children's task-based interactions. System 34: 547-565

Rahimpour , M \& Jahan, R. N. (2010). The Influence of Self-Efficacy and Proficiency on EFL Learners' Writing. Community College Journal of Research and Practice. 28: 663-675. Retrieved 20 June 2013 from www.itdl.org/Journal/Nov_10/article02.htm

Torrance, M \& Galibraith, D. (2006). The Processing Demands of Writing. In Charles A. MacArthur,Steve Graham,Jill Fitzgerald (Eds). Handbook of Writing Research, pp. 67-82. New York: Guilford Press. 